\title{
Chemical Composition of the Edible Oyster Shell Crassostrea Madrasensis (Preston 1916)
}

\author{
Ajith Thomas John*, Jency Mary
}

Department of Fisheries and Aquaculture, St.Albert's College, Ernakulam District, Kerala State, India

*Corresponding author: Ajith Thomas John, Department of Fisheries and Aquaculture, St.Albert's College, Ernakulam District, Kerala State, India

\begin{abstract}
Oysters coming under the Genus, Crassostrea and Saccostrea are observed along the Indian coasts. Among them four species are considered economically important including Crassostrea madrasensis ${ }^{[1]}$, Crassostrea gryphoides (Schlothein 1813), Crassostrea rivularis (Gould, 1850) and Saccostrea cucullata (Born, 1890). Crassostrea madrasensis, the dominant among them has been selected for this study. The procedure of analysis of the samples was based on AOAC 2005 standards. Flame Photometry, ICP and CHNS analysis was used to find out the precise values for $\mathrm{Ca}$ and $\mathrm{Na}$; $\mathrm{Sr}$ and $\mathrm{Mg}$; and $\mathrm{C}$ and $\mathrm{S}$ respectively in the shell of Crassostrea madrasensis. Calcium as calcium oxide was observed as the largest constituent at $47.49 \%$ closely followed by total Carbon at $43.87 \%$. The remaining elements Sodium as sodium oxide at $1.119 \%$, Magnesium as magnesium oxide at $0.619 \%$, Sulfur as sulfur dioxide at $0.403 \%$, Strontium as strontium oxide at $0.020 \%$ and water as moisture exist only in negligible percentages. The utilization of oyster shell relates to the chemical constituents which contribute more than $90 \%$ of the shell. In Crassostrea madrasensis, these elements have been identified as Calcium and Carbon and have been quantified as contributing on an average $91.36 \%$ by weight of the shell in this study. These can effectively be used in the pharmaceutical, fertilizer, lime, cement and poultry feed industries.
\end{abstract}

Received date: June 20, 2015

Accepted date: September 16, 2016

Published date: September 21, 2016

Citation: John, A.T., et al. Chemical Composition of the Edible Oyster Shell Crassostrea Madrasensis (Preston 1916) (2016) J Marine Biol Aquacult 2(2): 1- 4.

DOI: $10.15436 / 2381-0750.16 .972$

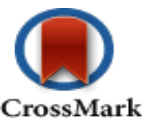

Keywords: Oysters; Crassostrea madrasensis; Shell composition; Utilization

\section{Introduction}

Along the Indian coast, oysters were identified and studied since the beginning of the $20^{\text {th }}$ century. One of the first records on the taxonomy of Indian oysters is by Hornell (1910) ${ }^{[2]}$. Since then a series of reports on the taxonomy of Indian oyster were made ${ }^{[1,3,4-9]}$. Originally the Indian oysters were referred to under the genus Ostrea but was later included under the genus Crassostrea. Another oyster genus Saccostrea was also recorded. In India, four species of oysters, coming under the subfamily Crassostrinae, including Indian backwater oyster Crassostrea madrasensis ${ }^{[1]}$, West coast oyster Crassostrea gryphoides (Schlothein 1813), Chinese oyster Crassostrea rivularis (Gould, 1850) and Indian rock oyster Saccostrea cucullata (Born, 1890), have been considered as economically important ${ }^{[9]}$. In addition to the above four, Bombay Oyster, Saccostrea cucullata, and gi- ant oyster Hyotissa hyotis are found in India. Among them Crassostrea madrasensis is the most abundant in Indian waters ${ }^{[10]}$.

Crassostrea madrasensis is essentially a brackish water oyster. It occurs as thick beds in estuaries, backwaters, ports and harbours and only sporadically on the open coasts. The oysters are found from the intertidal zone to a depth of about 4 meters. They colonize not only rocky or concrete surfaces but also hard muddy bottom where they thrive well. The general shape of the oysters varies in relation to the substratum. Those setting on flat rocky surfaces are round, those growing on soft mud are long and narrow, and those growing on uneven surface have shapes which conform to that of the substratum ${ }^{[11]}$.

Oyster shell is composed of protein polysaccharides and minerals including calcium magnesium, sodium, copper 
iron, nickel, strontium and some microelements. Chemical and microstructure analysis showed that oyster-shells are predominantly composed of calcium carbonate with rare impurities ${ }^{[12]}$. The oyster shell constitute about $90 \%$ of the total weight and contain $52.55 \%$ of calcium oxide and therefore are suitable raw material in calcium carbide, lime, fertilizer cement and other industrie ${ }^{[13]}$. The important use of mollusc shell is making lime. In Cox's Bazar region there are about 20 lime producing factories using around 8 MT dry shells per month. While in Khulna region about 30 lime factories were found to use around 12 MT shells per month ${ }^{[14]}$. In Orissa, the government used to lease out the oyster beds and the harvested shells are utilized for manufacturing poultry feed ${ }^{[15]}$. Oyster shells $(100 \mathrm{~kg})$ were disintegrated and shell grit of four different grades $5 \mathrm{~mm}, 2 \mathrm{~mm}, 1 \mathrm{~mm}$ and $<$ $1 \mathrm{~mm}$ were obtained. On trying them in a local poultry farm $2-3$ $\mathrm{mm}$ size grit was found to be suitable as an ingredient in poultry feed. The poultry and fish feed industry use $1-2 \%$ crushed shell in the feed preparation Solaiman, (2005).

Oyster shells are a waste product from mariculture that presents a major disposal problem in coastal regions such as south east Korea. It was found that pyrolysis of waste oyster shells under defined conditions $\left(750^{\circ} \mathrm{C}\right.$ for $1 \mathrm{hr}$ under a nitrogen atmosphere) transforms this material into a sustainable reagent for efficient (up to 98\%) removal of phosphate from waste water. In comparison, raw oyster shells removed almost no phosphate from water, whereas oyster shells heated to $75^{\circ} \mathrm{C}$ under an air atmosphere removed a moderate proportion (up-68\%) of phosphates from water ${ }^{[13]}$. X-Ray Diffraction (XRD) analysis of pyrolyzed oyster shells showed peaks that were characteristic of calcium oxide whereas analysis of raw oyster shells also differed from that of raw oyster shells. Preliminary economic feasibility analysis indicates that cost of activated oyster shell is competitive with other waste water treatment.

\section{Materials and Methods}

Crassostrea madrasensis was found distributed to a distance of about $15 \mathrm{~km}$ from Moothakunnam, Pallipuram, Gothuruth, Munambam, Azhikode. Samples were collected from Moothakunnam region during September 2011. Moothakunnam region is not polluted by way of discharge of domestic sewage, industrial wastes etc. and this region is suitable for oyster growth. Crassostrea madrasensis are distributed at a $5 \mathrm{~km}$ stretch in Moothakunnam region.

The collected Crassostrea madrasensis shell were kept inside a polythene bag and transported to our laboratory. The shell were cleaned of adhering organisms and detritus and scrubbed in running tap water to remove residual organic matter. After drying, the shells were grounded to a powder with using mortar and pestle. Three samples each containing $10 \mathrm{~g}$ shell powder was packed in tear bags. Parameters like moisture, ash, calcium, magnesium, strontium and sodium were detected in the Central Institute of Fisheries Technology, By-Products Laboratory, cochin. Calcium and sodium were detected using Flame Photometry and strontium and magnesium using Inductively Coupled Plasma Emission Spectroscopy (ICP). The procedure of analysis for both Flame Photometry and ICP was based on the Official methods of analysis of AOAC International, 2005 ${ }^{[16]}$. Total Carbon and Sulphur were detected at the Sophisticated Testing and Instrumentation Center (STIC) of the Cochin University of Science and Technology, Cochin using the Carbon Hy- drogen Nitrogen Sulfur (CHNS) analysis based on the Pregl-Dumas method. The results of the analysis are recorded graphically and the utilization of the shell of Crassostrea madrasensis is presented based on previous recorded studies.

\section{Results and Discussion}

Flame Photometry, ICP and CHNS analysis was used to find out the precise values for Calcium $(\mathrm{Ca})$ and Sodium $(\mathrm{Na})$; Strontium (Sr) and Magnesium (Mg); and Carbon (C) and Sulfur (S), respectively in the shell of Crassostrea madrasensis. The concentration of chemicals as per the test results are given in Table 1. The analysis results of the three methods mentioned, are represented in Figure 1, Figure 2 and Figure 3. Calcium as calcium oxide was observed as the largest constituent at $47.49 \%$ closely followed by total Carbon at $43.87 \%$. The remaining elements Sodium as sodium oxide at $1.119 \%$, Magnesium as magnesium oxide at $0.619 \%$, Sulfur as sulfur dioxide at $0.403 \%$, Strontium as strontium oxide at $0.020 \%$ and hydrogen as moisture exist only in negligible percentages. Others, constitute organic matter and Silicon $\left(\mathrm{SiO}_{2}\right)$, Chorine $(\mathrm{Cl})$, Aluminium $(\mathrm{Al})$, Iron (Fe), Phosphorous (P), Manganese (Mn), Fluorine (F), Potassium (K), Titanium (Ti), Boron (B), Copper $(\mathrm{Cu})$, Zinc $(\mathrm{Zn})$, Bromine (Br), and Iodine (I).

Table 1: Chemical composition of Crassostrea madrasensis shell in percentage.

\begin{tabular}{|l|l|c|}
\hline Sl. No. & Constituent & Concentration (\%) \\
\hline 1 & Calcium $(\mathrm{CaO})$ & 47.49 \\
\hline 2 & Total Carbon & 43.87 \\
\hline 3 & Sodium $\left(\mathrm{Na}_{2} \mathrm{O}\right)$ & 1.119 \\
\hline 4 & Magnesium $(\mathrm{MgO})$ & 0.619 \\
\hline 5 & Sulfur $\left(\mathrm{SO}_{2}\right)$ & 0.403 \\
\hline 6 & Strontium $(\mathrm{SrO})$ & 0.020 \\
\hline 7 & Moisture $\left(\mathrm{H}_{2} \mathrm{O}\right)$ & 0.8045 \\
\hline 8 & Others & 5.662 \\
\hline 9 & Total & $100 \%$ \\
\hline
\end{tabular}

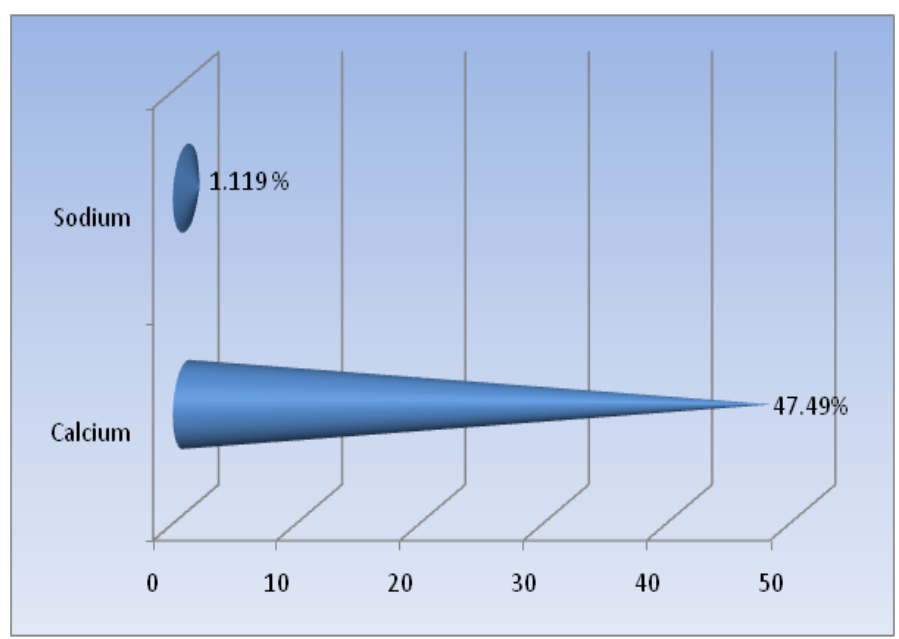

Figure 1: Calcium and Sodium content in Crassostrea madrasensis shell in percentage. 


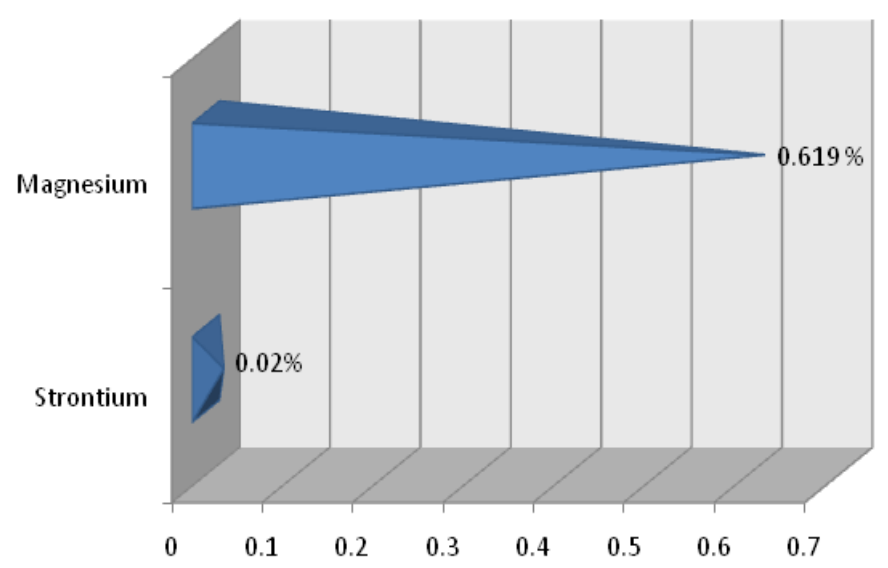

Figure 2: Magnesium and Strontium in Crassostrea madrasensis shell in percentage.

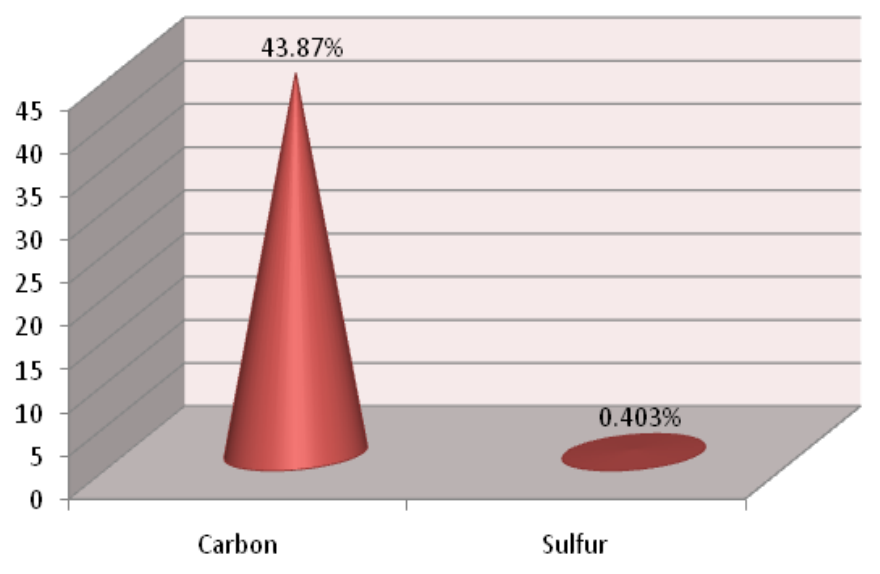

Figure 3: Total Carbon and Sulfur content in Crassostrea madrasensis shell in percentage.

The study conducted by Smith and Wright (1962) ${ }^{[17]}$ in Crassostrea virginica was used as guideline for the present study. In the present study, among the chemical constituents analyzed like Calcium, Carbon, Sodium, Magnesium, Sulfur, Strontium and Moisture, Calcium and Carbon were present in high concentrations while all the remaining constituents were observed at low values below $1.5 \%$. The concentration of Calcium carbonate in the shell of Crassostrea madrasensis constituted $91.36 \%$ by weight of the shell. This was lower than the value in Crassostrea virginica by Smith and Wright (1962) who recorded it at $95 \%$ by weight of the shell.

Smith and Wright (1962) $)^{[17]}$ found that the Calcium $(\mathrm{CaO})$ content in the shell of Crassostrea virginica was $54.6 \%$. In the present study for Crassostrea madrasensis, the percentage concentration of Calcium $(\mathrm{CaO})$ in the shell has been recorded at $47.49 \%$, which is a $7.11 \%$ variation between the two species. Concentration of Total Carbon at $43.87 \%$ was observed to be very close to that of $C$. virginica at $43.5 \%$. The concentration of Sodium $\left(\mathrm{Na}_{2} \mathrm{O}\right)$ in $C$. virginica was $0.32 \%$, while in this study for $C$. madrasensis it is $1.12 \%$. The analyzed value of Magnesium (MgO) in C. madrasensis shell was $0.619 \%$, which is comparatively larger than the previous study.

According to Smith and Wright $(1962)^{[17]}$ the Sulfur $\left(\mathrm{SO}_{2}\right)$ and Strontium $(\mathrm{SrO})$ of $C$. virginica are $0.16 \%$ and $0.12 \%$ respectively. But for $C$. madrasensis, it was observed as $0.403 \%$ and $0.02 \%$ respectively for these two elements. The concentration of moisture showed a slight variation between the two species, $0.58 \%$ in C. virginica and $0.804 \%$ in Crassostrea madrasensis.

The main purpose of the present study was to analyze the chemical composition of Crassostrea madrasensis shell and its utilization. This study was conducted taking samples from Moothakunnam region along the backwaters of Vembanad Lake. This result probably reflected the environmental factors affecting the growth of Crassostrea madrasensis shell. According to Galsoff (1964), Carriker $(1996)^{[18,19]}$ the nature of the bottom, salinity, temperature, current velocity, turbidity, direct sunlight, calcium concentration and chemical pollution are some factors suspected to change the shell morphology of oyster.

The result of chemical analysis of oyster shell ${ }^{[20]}$ showed that the bioavailability of calcium from oyster shell is superior to the calcium salt being used in allopathic medicine and the major elements Calcium, Magnesium, Sodium are essential for good and long health. Alagaraswami and Narasimham, (1973) ${ }^{[15]}$ and Narasimham and Kripa, (2007) ${ }^{[21]}$ also have reported the Crassostrea madrasensis shell used as raw material in fertilizer, Calcium carbide, lime, cement and poultry feed industries.

Yoon et al., 2003 ${ }^{[12]}$, conducted compressive strength tests for soil mortar specimens with varying blending ratio of cement, water, sand and oyster-shell and were compared with normal cement mortar. There was no significant reduction in the compressive strength up to $40 \%$ of dosages of oyster-shell instead of sand. The experimental results demonstrate that oyster-shells can be resources of pure calcareous materials and effective in replacement of sand, indicating promising reusable construction materials. Hence it can be assumed that the C. $m a$ drasensis resources of our waters can also serve as a replacement for sand for the construction industry.

Zhong et al., 2012[22], studied the effects of different addition amounts of oyster shell powder to ordinary Portland cement and methods of grinding on the strength and stability of cement mortar. The results indicated that when the addition amount of oyster shell powder is 5\%, compressive strength $(49.2 \mathrm{MPa})$ and rupture strength $(7.55 \mathrm{MPa})$ of the test piece are higher than those of blank samples without addition. Strength of the test pieces added with oyster shell powder at $10 \%$ is similar to that without addition. They also found that strength of cementing materials added with oyster shell powder obtained with wet ball grinding is higher than that afforded with dry ball grinding. From this it is clear that C. madrasensis shell powder can be added to ordinary Portland cement up to $10 \%$. Eutrophication of coastal waters due to enrichment by nutrients, especially phosphorus is a problem threatening the mariculture industry. Removal of phosphates from wastewater discharges to coastal water is an important component of Eutrophication control strategies. Hyok-Bo Kwon et al., 2004 ${ }^{[23]}$, while studying the waste disposal problems related to oyster shells found out that pyrolysis of waste oyster shells under defined conditions $\left(750^{\circ} \mathrm{C}\right.$ for $1 \mathrm{~h}$ under a nitrogen atmosphere) transforms this material into a sustainable reagent for efficient (up to 98\%) removal of phosphates from wastewater.

In conclusion, utilization of oyster shell relates to the chemical constituents which contribute more than $90 \%$ of the shell. In Crassostrea madrasensis, these elements have been 
identified as Calcium and Carbon (Li) have been quantified as contributing on an average $91.36 \%$ by weight of the shell in this study. Hence taking into consideration the various applications of these components in different fields, the following recommendations are made as a culmination of this study. Steps have to be initiated to extract the calcium salt from oyster shells for utilization in the preparation of allopathic medicines. Initiatives to be taken to improve the utilization of oyster shells used as raw material in fertilizer, Calcium carbide, lime, cement and poultry feed industries. Experiments to be conducted to ascertain the suitability of use of oyster shell as a substitute for sand. Further studies to be done towards the addition of up to $10 \%$ oyster shell powder to ordinary Portland cement to assess the impact on its strength and stability. Experiments to be conducted to use pyrolyzed oyster shells for Eutrophication control strategies.

Oyster farming to be promoted by the Government to improve the distribution and ensure the availability of this valuable resource for various industries.

\section{References}

1. Preston, H.B. Report on a collection of Mollusca from the Cochin backwaters. (1916) Rec Indian Mus 12: 27-39.

2. Hornell, J. Note on an attempt to ascertain the principal determining factor in oyster spawning in Madras presidency. (1910) Madras Fish Bull 4: 25-31.

3. Annandale, N., Kemp, S. Fauna of the Chilk Lake Mollusca Gastropoda and Lamellibranchiata. (1916) Mem Ind Mus 5: 329-366.

4. Gravely, F.H. Shells and other animal remains found on the Madras Beach.I.Groups other than snails etc. (Molluusca Gastropoda). (1941) Bull Madras Govt Mus N S Nat Hist 5 (1): 1-112.

5. Satyamurthi, S.T. The Mollusca of Krusadai Island (in Gulf of Mannar)II. Scaphopoda, Pelecypoda and Cephalopoda. (1956) Bull Madras Govt Mus (New Ser) Nat Hist Sect 1(2)7: 202.

6. Durve, V.S. On the nomenclature of two Indian back water oysters. (1968) J Mar Biol Ass India 9: 173-178.

7. Rao, K. Sathyanarayana. Chap.II. Edible bivalves Mussels and oysters, In: The Commercial Molluscs of India (1974) Bull Cen Mar Fish Res Inst 25: 4-39.

8. Rao, K.S. Taxonomy of Indian Oysters. (1987) Bulletin of Central Marine Fisheries Research Institute 38: 59-62.
9. Rao, K.S., Rajapandian, M.E., Muthiah, P., et al. The Indian edible oyster. Technology of seed production and farming. (1992) CMFRI publication 23 .

10. James, P.S.B.R., Narasimham, K.A., Rao, K.S. Prospects for development of oyster culture in India. (1993) Marine Fisheries Information Service. No.125. Central Marine Fisheries Research Institute, ICAR

11. Rao, K.V., Nayar, K.N. Rate of growth in spat and yearlings of the Indian backwater oyster, Ostrea madrasensis Preston. (1956) Indian J Fish 3(2): 231-260.

12. Yoon, G.I., Kim B.T., Kim, B.O., et al. Chemical-mechanical characteristics of crushed oyster-shell. (2003) Waste Manag 23(9): 825-834.

13. Dholakea, A.D. Fisheries and Aquatic Resources of India. (2004) Daya Publishing House 53-54.

14. Solaiman, M. Mollusc Marketing System through Value chain Analysis with Special Emphasis on Lively hood of the Poor Fishermen. (2005) 32-48.

15. Alagarswami, K., Narasimham, K.A. Clam, Cockle and Oyster resources of the Indian Coasts. (1973) Proc. Symposium on Living Resources of the Seas around India 86-87.

16. A.O.A.C. 2005 Official Methods of Analysis of AOAC International 18th Ed., AOAC International: USA Chapter 35: 8-950.46, Chapter 39. pp 1

17. Smith, R.A., Wright, E.R. Elemental Composition of Oyster shell. (1962) Texas Journal of Science 14(2): 222-224.

18. Galtsoff, P.S. The American oyster Crassostrea virginica Gmelin.U.S. (1964) Fish and wild life Serv Fish Bull 64: 430-441.

19. Carriker, M.R. The shell and ligament. Kennedy, V.V. R.I.E.Newell and Ebke, A.F. (Eds.) The Eastern Oyster, Crassostrea virginica. (1996) Sea Grant College Park, Maryland 75-159.

20. Ehsan, A.M., Ehsan, S., Khan, I.H. and Khan, M.S. Spectroscopic and Chemical Evaluation of Oriental medicine (Oyster shell Pearl and Coral). (2005) Journal Chemical Society of Pakistan 27(5): 512-517

21. Narasimham, K.A., Kripa, V. Text book of Oyster biology and culture in India. (2007) Indian Council of Agricultural Research 8: 86-89. 22. Zhong, B.Y., ZHOU, Qiang., CHAN, Chang-Feng., et al. Structure and Property Characterization of Oyster Shell Cementing Material. (2012) Chinese J Struct Chem 31(1): 85-92.

23. Hyok-Bo, Kown., Chan-won, Lee., Byung-Sei, Jun., et al. Recycling waste oyster shell for eutrophication control. (2004) Resources, Conservation and Recycling 41(1): 75-82.
Ommega Online Publishers

Journal Title: Journal of Marine Biology and Aquaculture Journal Short Name: J Marine Biol Aquacult
Journal ISSN 2381-0750

E-mail: marinelife@ommegaonline.org

Website: www.ommegaonline.org 